\title{
Research on the Impact of International Oil Prices on the Economy of Russia
}

\author{
Jiuxia $\mathrm{Wu}$ \\ International Business School, \\ Tianjin University of Finance and Economics, Hexi Distract, Tianjin, 300202, China
}

\begin{abstract}
In the process of Russian economic development, the oil industry is one of the important pillar industries. More than $50 \%$ of the total revenue of the Russian government comes from the oil and gas industry. Oil and oil products exports account for about 56.9\% of Russia's total export[1]. So Russia's economy is inextricably linked to oil prices. Rosneft's role in budgetary revenue sources is growing. In the development of the world economy, the change of international oil price affects the development of the Russian economy. This paper reviews the relevant theories about the relationship between oil price and Russia's economic growth. Besides, the short-term and long-term effects of oil price fluctuation on Russian economy are analyzed with Keynes's income determination theory and "resource Curse" theory[2] respectively. In addition, the granger causality test is used to analyze the relationship between the fluctuation of oil price and the change of Russian GDP. The following conclusions are drawn from the analysis. Firstly, oil price rise is beneficial to Russian economic growth in the short term, but will hinder Russia's economic long-term development. Secondly, the fluctuation of oil price is the granger cause of the change of Russian GDP. However, the change of Russian GDP is not the granger cause of the fluctuation of oil price.
\end{abstract}

\section{INTRODUCTION}

From September 2017 to March 2018, the European Union imposed economic sanctions on Russia, coupled with the "cold winter" of oil price, and Russian economy declined rapidly. This is mainly because Russia's national economic growth mainly depends on energy. Once the foreign economy is blocked and energy is not imported, Russia's economy will decline. In order to develop its economy without being restricted by other countries, Russia must transform the "digging and selling" of energy into increasing the added value and technical content of domestic energy manufacturing products, and promote the development of petrochemical industry with modern technology. Looking back on Russia's history, it is not difficult to find that if the oil price falls, Russia's economy will be greatly impacted. Therefore, it is of great significance to analyze the impact of Russian oil price fluctuations on economic development through empirical analysis.

Generally speaking, the larger the proportion of natural resource income in the government's total income is, the more dominant position of natural resource industry in the economy will be, and the more prominent the social and economic problems such as political corruption, social instability, and the soaring unemployment rate will become. Russia is one of the important oil and gas producing and exporting countries in the world. Its economy depends on energy export. In 2014, oil and gas accounted for $50 \%$ of the Russian Federation's fiscal revenue. By 2015, the proportion was more than half, reaching $68 \%$. The roller coaster of international oil price seriously affects the prosperity of the Russian economy. This paper will discuss the impact of oil price fluctuation on Russian economy and analyze the impact of international oil price on Russian Federation's finance, GDP, trade balance and import and export. Based on Keynes theory, this paper makes a quantitative analysis of the impact of oil price fluctuation on Russian economy, and then makes a quantitative analysis of oil price on Russian economy according to Granger causality test.

\section{TRANSMISSION MACHANISM OF THE INFLUENCE OG INTERNATIONAL OIL PRICE ON THE ECONMONY OF RUSSIA}

\subsection{Short term impact of oil price fluctuation on Russian economic growth}

According to Keynes's theory, the national income of a country is mainly determined by the total demand in the short term, i.e. $\mathrm{y}=\mathrm{ad}=\mathrm{C}+\mathrm{I}+\mathrm{G}+\mathrm{NX}$, where $\mathrm{y}$ is the national income, ad is the total demand, $\mathrm{C}$ is consumption, $\mathrm{I}$ is investment, $\mathrm{G}$ is government purchase, 
and NX is net export. The fluctuation of oil price has an impact on Russia's economic growth through its influence on Russia's consumption, investment, government purchase and import and export.

The impact of oil price change on consumption is mainly due to its impact on the real income of residents. Due to the single economic structure, Russia's export products are mainly oil, natural gas and other natural resources as well as arms, while a large number of industrial manufactured products such as food, daily necessities, vehicles and electronic products need to be imported. Russia's economic GDP decline has intensified with the decline of crude oil price. When the price of oil rises, on the one hand, Russia gains a large amount of income from exporting oil, thus increasing its nominal income; In addition, the US dollar obtained from exporting oil also guarantees the stability of the ruble currency, reduces the price of imported products, thus reducing the inflation rate, which further improves the actual income, thus promoting consumption. According to figure 1 , when the oil price is relatively stable, the exchange rate of the US dollar against the Russian rouble is also relatively stable. In contrary, when the oil price drops sharply, the exchange rate of the US dollar against the Russian rouble transforms significantly such as in 2009 and 2015.

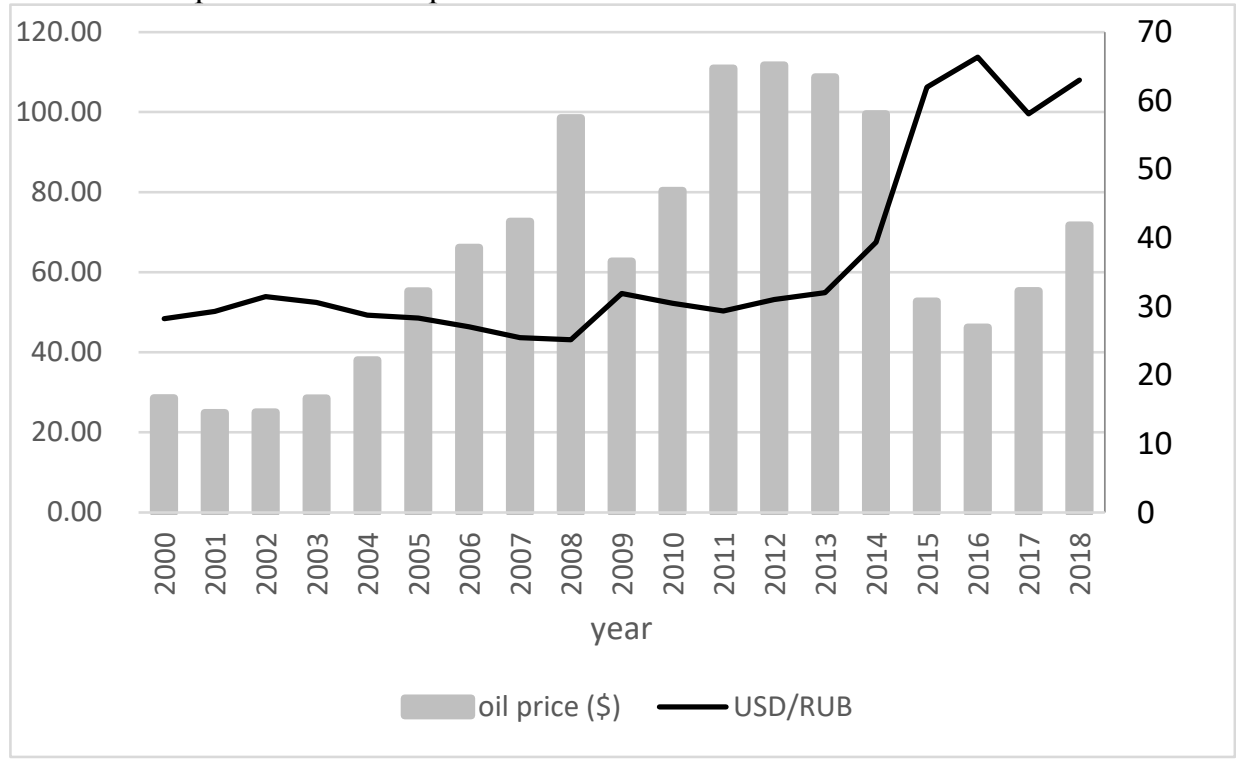

Figure 1. Oil price and the inflation from 2000 to 2017.

When the oil price rises, as a net exporter of oil, Russia's investment is expected to be increased, and the scale of investment received may increase substantially, and the investment mainly flows to the oil related sectors with high return on domestic income, which will improve the economic growth in Russia. When the oil price falls, the investment scale may continue to decline, hindering the growth of Russian economy.

Oil and gas revenue is an important part of Russia's fiscal revenue. In 2012, for example, oil and gas revenue accounted for more than half of Russia's fiscal revenue, reaching $50.24 \%$. So the amount of Russian government spending is closely related to the oil price. When the oil price rises, the government's fiscal revenue increases, so the expenditure increases. On the contrary, the expenditure decreases. According to figure 2, we can notice that the higher oil price is, the higher government expenditure is, which prove the theory except some special cases. 


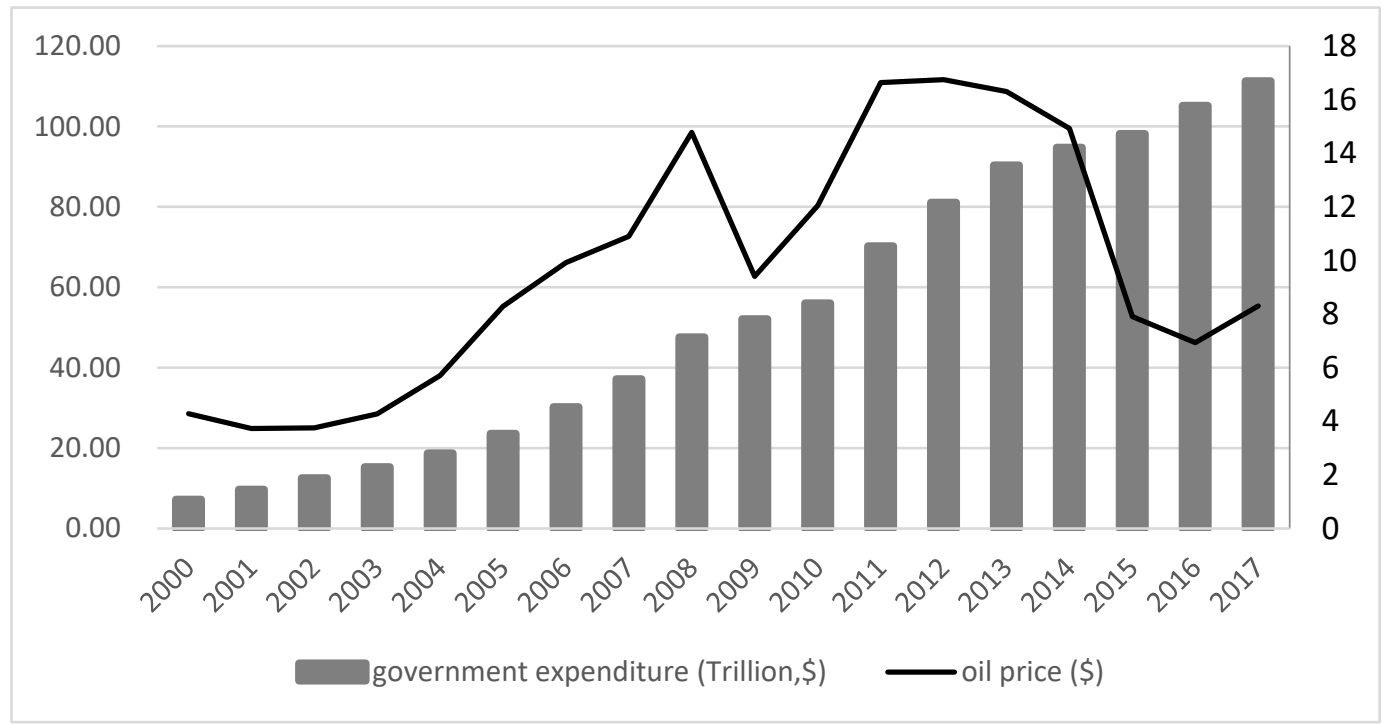

Figure 2. GDP of Russia and government expenditure from 2000 to 2017.

There are two main channels for the impact of oil price fluctuations on net exports. On the one hand, as the main export commodity of Russia, the fluctuation of oil price will cause the fluctuation of Russia's export volume, and then affect the net export. When oil prices rise, net exports increase; when oil prices fall, net exports decrease. On the other hand, the dollar that Russia obtains through the export of oil is the guarantee of ruble currency value. When the oil price rises, the dollar assets held by Russia increase, the ruble appreciates, the price of exported goods increases, other countries is not willing to bear the price and the net export decreases. When the price of oil falls, then the dollar devalues. As a result, the ruble depreciates, and the price of exported goods decreases. That is beneficial to the imparted countries and the net export increases. According to the figure, we can notice that the higher oil price is, the higher net export is, which prove that oil account for a large part in the Russia's export volume. So the fluctuation of oil price will have a intense effect on the trade.

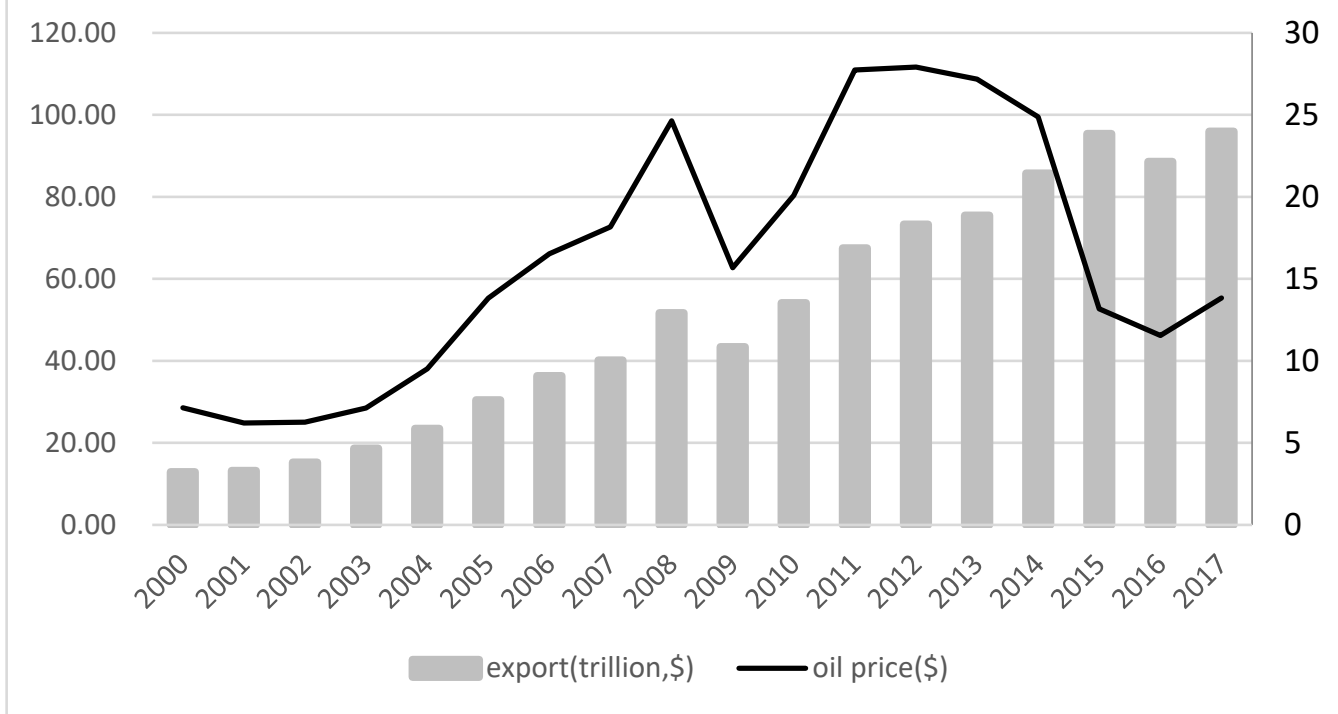

Figure 3. GDP of Russia and the export volume from 2000 to 2018.

\subsection{Long term impact of oil price fluctuation on Russian economic growth}

The long-term impact of oil price fluctuation on Russian economic growth can be analyzed by the theory of "resource curse". Resource curse refers to the fact that the enrichment of natural resources does not promote the economic development of a country, on the contrary, it makes a country too dependent on the resource exploitation industry and ignore the development of other industries, so that the economy loses the ability of sustainable development. From the perspective of the world, those countries rich in natural resources, such as Saudi Arabia, Iran and Sudan, only achieved rapid economic growth in the short term when natural resources were discovered. In the long term, due to excessive dependence on the exploitation of natural resources, other industries developed slowly and economic growth slowed down. When the oil price rises, 
on the one hand, due to the high yield of the oil sector, a large number of capital and labor are invested in the oil related industries, resulting in the manufacturing sector has to attract labor with higher wages, which makes the competitiveness of the manufacturing industry decline. On the other hand, a large amount of foreign exchange income brought about by high oil price makes ruble appreciate, which weakens the international competitiveness of Russian manufacturing industry. Therefore, in the long run, the rising oil price will bring a serious blow to Russia's manufacturing industry and affect the sustainable growth capacity of Russia's economy. When the oil price falls, on the one hand, the depreciation of ruble makes Russian goods more competitive in the international market, on the other hand, the decline of energy industry income can also force the Russian government to accelerate the development of other industries. Therefore, in the long run, the decline of oil price can promote the development of Russian manufacturing industry and accelerate the rationalization of the economic structure of the government, which is of great benefit to the long-term economic growth of Russia.

\section{EMPIRICAL STUDY OF IMPACT OF INTERNATIONAL OIL PRICE ON THE ECONOMY OF RUSSIA}

\subsection{Data Selection}

According to the above analysis, there is a close relationship between Russian economic growth rate and oil price. Now, through the Granger causality test to determine whether there is a statistically significant correlation between the two. At present, there are three kinds of international oil benchmark prices, namely, New York Mercantile Exchange light and low sulfur crude oil futures price, London international oil exchange North Sea Brent crude oil futures price and Dubai crude oil futures price. Russia's oil is mainly sold to Europe, so the price of Brent crude oil in the North Sea is the benchmark. Therefore, the price of Brent crude oil in the analysis process is the price of Brent crude oil in the North Sea. In order to increase sample size, yearly data from 2000 to 2018 are used for analysis. According to the figure, we can notice that oil price has obvious relationship with the GDP of Russia.

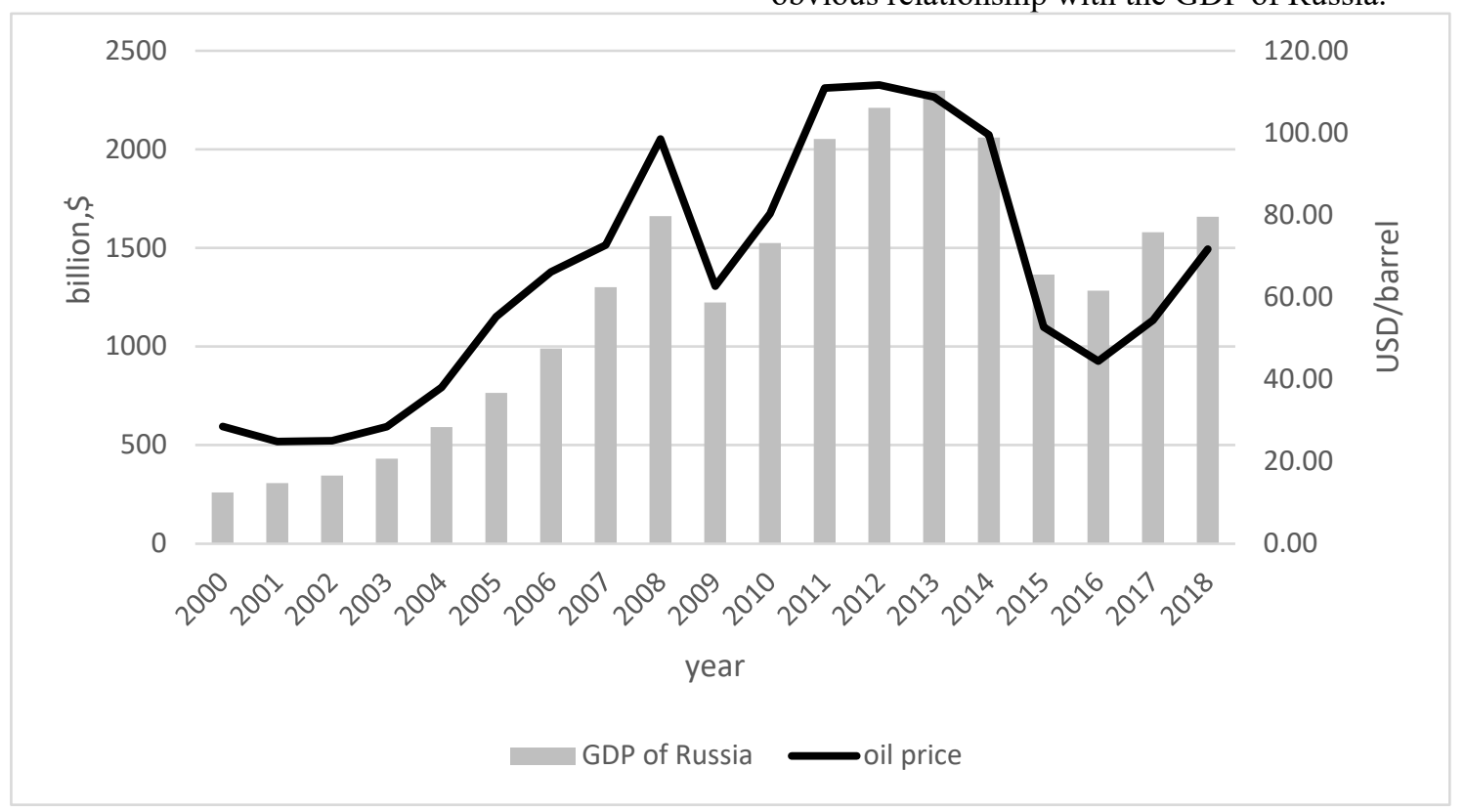

Figure 4. GDP of Russia and the oil prise from 2000 to 2018.

\subsection{Stability Test}

Take the logarithm of oil price and Russian GDP respectively, get the sequence lnoil and lngdp, and use Stata to test the stability of these two sequences. The $t$ statistic values of lnoil and lngdp are both large, so the original hypothesis that unit root exists in the sequence cannot be rejected. Therefore, lnoil and lngdp are non-stationary series. In order to eliminate the unit root, the first-order difference is applied to the sequence lnoil and lngdp. The sequence after the difference is dlnoil and dlngdp respectively. And then test the stability of dlnoil and dlngdp.

The values of dlnoil and dlngdp $\mathrm{T}$ statistics are less than the critical value of $10 \%$ level, so the original hypothesis is rejected. That is, both dlnoil and dlngdp are stationary sequences. Because lnoil and lngdp become stable series after one difference, there is a unit root in both series, that is, there is a co integration relationship between the two series. So we can test the granger causality of dlnoil and dlngdp. The results are as follows: 
TABLE I Dickey-Fuller test result.

\begin{tabular}{ccccc}
\hline Variable & Test Statistic & $\mathbf{1 0 \%}$ critical value & P-value for $\mathbf{Z}(\mathbf{t})$ & Conclusion \\
\hline lngdp & -2.323 & -2.630 & 0.1648 & Nonstationary \\
lnoil & -1.591 & -2.630 & 0.4883 & Nonstationary \\
\hline
\end{tabular}

TABLE II Dickey-Fuller test result.

\begin{tabular}{ccccc}
\hline Variable & Test Statistic & $\mathbf{1 0 \%}$ critical value & P-value for $\mathbf{Z}(\mathbf{t})$ & Conclusion \\
\hline dlngdp & -2.788 & -2.630 & 0.0600 & stationary \\
dlnoil & -3.311 & -2.630 & 0.0144 & stationary \\
\hline
\end{tabular}

\subsection{Granger causality test}

TABLE III Granger causality test result.

\begin{tabular}{c|cc}
\hline Null Hypothesis & F- Statistic & Prob $>$ F \\
\hline dlngdp does not Granger Cause dlnoil & 2.26 & 0.1552 \\
dlngdp does not Granger Cause dlnoil & 4.68 & 0.0483 \\
\hline
\end{tabular}

It can be seen from the test results that at $90 \%$ confidence level, the change of Russian GDP is not the granger cause of the change of oil price, while the change of oil price is the granger cause of the change of Russian GDP. The granger reason for the change is not the change of oil price is. For one thing, Russia is only the second largest country in oil export, while its oil consumption is only one eighth of that of the United States and one third of that of China. Hence, it is difficult for the change of Russian economic situation to have a greater impact on oil demand and production and cannot affect the oil price, either. For another, Russia produces stone Oil does not control the pricing power of oil, so it is difficult to have a greater impact on oil prices. Oil price change is the granger reason of Russia's GDP change, because oil price change will affect Russia's consumption, investment, government purchase and net export, thus affecting Russia's GDP.

\section{SUGGESTIONS}

\subsection{Improvement and adjustment into the domestic industrial structure}

A rich resource, developed industries and good economic indicators are conducive to a country's foreign trade and economic growth to a certain extent, but they will also cause a country to rely excessively on its comparative advantages, and economic growth only depends on oil will inevitably affect national security. In reality, many countries with abundant natural resources grow more slowly than those with frequent natural resources. Because, if a country's economic growth point is only oil and depends on a single resource, then the welfare level of the country is subject to the fluctuation of international oil price.[3] When the oil price falls, the social welfare level of a country will drop sharply.

For a long time, Russia's economic development is mainly depend on development of energy economy, mining metallurgy, oil processing and other industries, while the development of light industry is relatively backward. Russia's economic structure is single and its ability to withstand economic crisis is weak. Therefore, Russia's economy is particularly affected by changes in international crude oil prices. First of all, we should rectify the enterprises involved in the oil industry chain, such as the field of oil mining enterprises. Russia's light industry exports have been declining. Manufacturing industry is the main body and material basis of industrialized countries. It reflects the scientific and technological level and comprehensive strength of a country, and is an important symbol and embodiment of a country's international competitiveness. Russia should strengthen policy support and investment, adjust its industrial structure, change its dependence on energy export, strengthen technological innovation, encourage and support the export of high-tech products, and increase investment in manufacturing producing countries and regions, so as to achieve the purpose of improving its international competitiveness.

\subsection{Innovation and development into petroleum related technology}

Russia is rich in natural resources. Russia's natural resources assets are located between the Ural Mountains and the central plain of Siberia. Other major producers include the Timan mountain peach in northern Russia, the Volga Ural region along the Pacific coast, and Sakhalin Island. 
Russia has been committed to energy and economic development over the years, but its crude oil processing technology, crude oil processing depth and oil product richness are far lower than those of the United States, Canada, Japan and other countries. The rapid development of offshore oil resources, is very difficult, and there has been little no substantive progress. Remarkable results have been achieved in oilfield exploitation, but there is still a long way to go. The modernization of the refinery has achieved initial results. Petroleum products have entered the European Union in an all-round way. The main products Russia exports are crude oil and petroleum products. The added value of these oil products is too low, which affects Russia's profit distribution in the trading system[4]. Therefore, Russia should innovate the equipment and technology of its crude oil and natural gas industry, greatly increase the export volume of oil, and make full use of its comparative advantages. At present, Russia's pipeline transportation system is not perfect. In order to overcome the obstacles of oil export and further tap and improve the potential of oil export, Russia should make large-scale investment in oil pipeline construction, which is particularly important to ensure the efficiency and safety of oil export.

\subsection{Integration into international oil pricing system}

As the fluctuation of international oil price has a significant impact on Russia's economy, Russia's economic development can be controlled by developing domestic futures market and maintaining the stability of domestic financial market, integrating into the international oil pricing system, and improving Russia's oil pricing power[5].

\section{CONCLUSION}

Oil plays an important role in Russia's economic development. It is the main source of its fiscal revenue and foreign exchange revenue. It is also an important part of Russia's foreign trade development and economic development. The fluctuation of international oil price has a huge impact on Russia's international economy.

First of all, the fluctuation of international oil price has a negative impact on Russian economy, resulting in the reduction of Russian government's fiscal revenue, the greater impact on the volume of import and export trade, and a certain impact on the inflation rate and exchange rate. Besides, the fluctuation of international oil price has a great influence on Russia's economic development, mainly being affected by Russia's domestic oil endowment. Domestic and foreign trade is the dominant way for the exportation of oil. On the other hand, the trade structure mainly crude oil export has a great influence. At the same time, oil pricing power also affects the fluctuation of international oil price.

Secondly, an empirical analysis on the impact of international oil price fluctuations on Russia's domestic economy is made. In addition, a quantitative analysis on the impact of international oil price on Russia's domestic economy from the empirical aspect is conducted in this paper.

Based on the theoretical and empirical analysis of the impact of international oil price fluctuations on Russia's economy, and the negative impact of international oil price fluctuations on Russia's economy, combined with the reasons for the impact of international oil price on Russia's economy, this paper puts forward targeted suggestions.

\section{ACKNOWLEDGMENT}

First of all, I'd like to thank my professor for giving me a lot of professional advice from the beginning of the thesis to the later revision. Secondly, I would like to thank my TA and thesis tutor for their careful answers to all the problems I have encountered in the process of writing my thesis. I also want to thank my friends and family, who gave me a lot of spiritual support in the process of writing my thesis. Finally, I would like to thank Tianjin University of Finance and economics for providing me with a good educational environment and a good learning atmosphere.

\section{REFERENCES}

1. M. Ivan. Research on the influence of international oil price fluctuation on Russian economy. Harbin: Harbin Institute of Technology. 2019

2. Y. Li, Y. Zhao. The impact of oil price fluctuation on Russian economic growth. Money China, 2017, 000(021): 20-22.

3. J. Zhang. A study on the effect of natural resources on economic growth. Southwest University of Finance and economics. 2008

4. R. Huang, Z. Cai. The influence of international oil price fluctuation on Russian economy. Money China, 2016(05) 65-70

5. Y. Khvesko. Economic impact of international oil prices on Russia. Harbin: Harbin Institute of Technology. 2018 